\title{
Proliferation Security Initiative: A New Formula for WMD Counter-Proliferation Efforts?
}

\author{
Szymon Bocheński ${ }^{*}$
}

\section{Introduction}

For many years, the worldwide non-proliferation regime-with its core element, the Non-Proliferation Treaty (NPT) - has prevented nuclear proliferation on a global scale. The number of states known to possess nuclear weapons has risen from five in 1968 to eight in 2004. ${ }^{1}$ The estimates in the early 1960 s held that there could emerge as many as thirty or forty nuclear powers in twenty years' time. ${ }^{2}$ Although the NPT constitutes a major pillar of the multilateral system of collective security, it must be acknowledged that it is fragile and has been seriously weakened by developments of the recent past. ${ }^{3}$ The list of challenges to the NPT includes the lack of universality, a crisis of non-compliance, and insufficient safeguard mechanisms. These weaknesses have been highlighted by the emer-

Szymon Bocheński is an Attaché at the Polish Ministry of Foreign Affairs in Warsaw. The views presented here are his, and do not represent official positions of the Polish government.

1 This number could be questionable because Israel has never officially confirmed that it has nuclear weapons. There are also some doubts about the DPRK nuclear test in 2006, which suggest that this was a failed attempt.

2 Tom Sauer, "The Nuclear Non-proliferation Regime in Crisis," Peace Review: A Journal of Social Justice 18 (2005): 333; Waheguru Pal Singh Sidhu and Ramesh Thakur, "Managing the Nuclear Threat After Iraq: Is It Time to Replace the NPT Paradigm?" in Arms Control After Iraq: Normative and Operational Challenges, ed. Sidhu and Thakur (New York: United Nations University Press, 2006), 1.

3 The incomplete list of alarming signals with regard to the condition of the non-proliferation regime could include the following events: in 1998, India and Pakistan tested nuclear bombs, de facto becoming nuclear states outside the non-proliferation regime; despite UNSC sanctions, Iran continues to develop its nuclear program under the cover of peaceful and civilian purposes; the Comprehensive Test Ban Treaty has never entered into force, and negotiations on the Fissile Material Cutoff Treaty are stalled; and a majority of countries feel that the five original nuclear-weapon states do not intend to fulfill their NPT obligations to eliminate nuclear weapons, which reduces their willingness to obey treaty obligations and agree to further strengthen the regime. While Libya's renunciation of its nuclear program, although it counts as a positive development, also revealed the existence of extensive proliferation networks, such as that spawned by the Pakistani weapons scientist A. Q. Khan. 
gence of the terrorist threat and the issue of so-called "failed states."

The fact is that "the international proliferation environment has changed, and that this has exposed gaps in the existing non-proliferation arrangements." In order to close these gaps there is a need for designing new non-proliferation instruments and strengthening existing ones. This paper will not concentrate on the issues of the erosion of the non-proliferation regime and the problems that face it. Instead it will evaluate the prospects of the Proliferation Security Initiative (PSI) to become a tool capable of addressing new proliferation challenges. The PSI, announced by U.S. President George W. Bush in May 2003, is an endeavor to build an international partnership of like-minded countries which, using their own laws and resources, will try to thwart illegal transfers of dangerous technologies by proliferation networks as well as by states. The PSI redefines existing norms, introducing the word "counter-proliferation" to the non-proliferation vocabulary.

In its first part, this paper refers to the origins, history, and basic concepts of the PSI. It outlines the spirit of the PSI and explains the philosophy of this proactive, flexible, and coalition-based approach to non-proliferation. This section also argues that interdiction operations are not the sole manifestation of PSI activities. There are also workshops, exercises, and seminars that have significant addedvalue and should be taken into account when assessing the PSI's overall effectiveness.

The third section of the essay identifies the practical and operational limits of the Initiative (especially considering interdiction operations, intelligence sharing, and dual-use goods) and recognizes legal challenges to the Initiative, as well as those stemming from the geographical and material dimensions of the PSI (outreach strategy). It also assesses the extent to which the Initiative can influence developments in the Democratic People's Republic of Korea (DPRK) and Iran.

Four years into the PSI, it is a challenging task to estimate whether or not it is an efficient instrument to address current challenges. PSI achievements are confidential, and its balance is not clear. Moreover, research on this subject is hindered by the fact that available sources are modest and limited to PSI countries. Despite these difficulties, I tried to ensure objectivity in my research and take into account the anxieties of countries that are not PSI participants. This paper concludes with

4 The UN High-Level Panel of Threats, Challenges and Change in its conclusions states that: "the nuclear non-proliferation regime is now at risk because of lack of compliance with existing commitments, withdrawal or threats of withdrawal from the Treaty on the Non-Proliferation of Nuclear Weapons to escape those commitments, a changing international security environment and the diffusion of technology. ... We are approaching a point at which the erosion of the non-proliferation regime could become irreversible and result in a cascade of proliferation."

5 John Simpson, “The Nuclear Non-proliferation Regime: Back to the Future?" Disarmament Forum 1 (2004). 
identifying a set of policy recommendations that could contribute to further strengthening the role of PSI in countering new proliferation challenges.

\section{PSI: History and Origins}

Although the PSI was announced by President George W. Bush on 31 May 2003 in Krakow, Poland, the origins of this instrument can be discovered within the Clinton Administration. "It was under President Clinton that a gradual policy shift towards counter-proliferation was initiated," but still within a broader non-proliferation framework. ${ }^{6}$ For example, in 1993 then-Secretary of Defense Les Aspin announced the creation of the Defense Counter-Proliferation Initiative, designed to deal with the fear that after the dissolution of the Soviet Union some WMD could fall into the hands of irresponsible states or terrorist groups. ${ }^{7}$ Also, in August 1993, the United States carried out an interdiction operation against the Chinese ship Yinhe, which was suspected of transporting dangerous chemical substances. ${ }^{8}$ A similar situation occurred in 2002 when the U.S. and Spain discovered Scud missile parts onboard a North Korean vessel (So San) heading to Yemen. The incident brought to policymakers' attention the importance of preventive measures in the fight against WMD proliferation. ${ }^{9}$

By coincidence, the So San case coincided with a time when the "U.S. National Strategy to Combat WMD" was announced. The new strategy formally introduced counter-proliferation as a primary way of preventing possession of WMD by hostile states and terrorists. Moreover, it recognized interdiction as a main tool of counter-proliferation efforts. With regard to its implementation, the Strategy indicated the need for strengthening cooperation with like-minded states. ${ }^{10}$ To sum

6 Peter Van Ham, "WMD Proliferation and Transatlantic Relations: Is a Joint Western Strategy Possible?" Netherlands Institute of International Relations (Clingendael Institute) (April 2004), 9.

7 British American Security Council, "PSI: Combating Illicit WMD Trafficking, 2006," (2005), available at www.basicint.org/nuclear/counterproliferation/psi.htm.

8 The attempt failed because U.S. authorities were forced to wait several weeks for a permission to search the vessel. During this time the chemicals vanished. Andrew C. Winner, "The Proliferation Security Initiative: The New Face of Interdiction," The Washington Quarterly 28:2 (Spring 2005): 130.

9 Despite the fact that, after talks with Yemen, the shipment wasn't stopped (probably because the U.S. was interested in Yemeni support for antiterrorist activities). For more details on the interdiction of the So San, see Winner, "The Proliferation Security Initiative," and Rebecca Weiner, "Proliferation Security Initiative to Stem Flow of WMD Material," Center for Non-proliferation Studies at the Monterey Institute of International Studies (16 July 2003), available at: http://cns.miis.edu/pubs/week/030716.htm.

${ }^{10}$ U.S. National Strategy to Combat Weapons of Mass Destruction (2002), available at www.whitehouse.gov/news/releases/2002/12/WMDStrategy.pdf. 
up, the practice, as well as U.S. documents, heralded the creation of PSI as a proactive approach to non-proliferation. ${ }^{11}$

According to U.S. officials and available documents, PSI is aimed at states and non-state actors of proliferation concern to enable interdiction of illegally transferred WMD, their delivery systems, and related materials. ${ }^{12}$ Participants, through cooperation, introduce effective measures to impede and stop the flow of WMD and to interdict any potential shipment transported by sea, air, or land.

The founding group of the PSI consisted of eleven countries. ${ }^{13}$ During the four years of its existence, the PSI has gained global response. Today, support for the goals of the PSI is expressed by around eighty states ${ }^{14}$ and international institutions like the UN and NATO. ${ }^{15}$ As of the end of 2006, the group of participants continuously engaged in PSI activities consists of twenty states. ${ }^{16}$

\section{Legal Basis}

The Proliferation Security Initiative is not an international organization nor a treaty, nor even a formal alliance. That is why it does not have a statute. The only official document that sets forth an outline for PSI activities is the Statement of Interdiction Principles, which was agreed on 4 September 2003 in Paris. By signing this agreement, a state commits itself to "establish a more coordinated and ef-

11 The concept of the PSI illustrates the evolving mind-set of the Bush Administration, which lacks trust in the efficacy of multilateral institutions and is trying to pursue U.S. foreign policy goals with support of like-minded states creating ad hoc coalitions. Since 9/11, in addition to PSI, the following initiatives based on such an approach were announced: Container Security Initiative, the Customs-Trade Partnerships against Terrorism, the Regional Maritime Security Initiative, the Global Threat Reduction Initiative, and the Global Initiative to Combat Nuclear Terrorism.

12 Statement of Interdiction Principles (4 September 2003), available at www.state.gov/t/isn/ rls/fs/23764.htm; John R. Bolton, "An All-out War on Proliferation," The Financial Times (7 September 2004), available at www.state.gov/t/us/rm/36035.htm.

13 These were: Australia, France, Germany, Italy, Japan, the Netherlands, Poland, Portugal, Spain, the United Kingdom, and the United States.

14 Their level of engagement in PSI activities varies, from the states that have never participated in any of them to those that actively take part in exercises.

15 "The Alliance underscores its strong support for the aims of the Proliferation Security Initiative (PSI) and its Statement of Interdiction Principles to establish a more co-ordinated and effective basis through which to impede and stop shipments of WMD, delivery systems, and related materials flowing to and from states and non-state actors of proliferation concern." NATO Istanbul Summit Communiqué (28 June 2004), available at www.nato.int/ docu/pr/2004/p04-096e.htm.

${ }^{16}$ Argentina, Australia, Canada, Denmark, France, Germany, Greece, Italy, Japan, the Netherlands, New Zealand, Norway, Poland, Portugal, Russia, Singapore, Spain, Turkey, United Kingdom, and the U.S. 
fective basis through which to impede and stop shipments of WMD, delivery systems and related materials flowing to and from a states or non-state actors of proliferation concern." The statement does not explicitly name the category of "states or non-state actors of non-proliferation concern." However, it mentions that it refers to those actors that "are engaged in proliferation through: (1) efforts to acquire chemical, biological, or nuclear weapons and associated delivery systems; or (2) transfers of WMD, their delivery systems, or related materials." This deliberate lack of clarity in defining the possible subjects of interdiction efforts could create double standards in the treatment of various countries. On the other hand, it ensures the flexibility of the PSI. ${ }^{17}$ The statement further obliges participants to work to strengthen their internal institutions and laws in order to back up PSI aims and enumerates specific actions that could be taken in support of interdiction efforts.

There is one specific category of official documents that is signed under the auspices of PSI: ship-boarding agreements. These are bilateral agreements signed between the U.S. and so-called "flag-of-convenience" states. ${ }^{18}$ According to these agreements, if a specific ship holds the nationality of the U.S. or the partner country, and is suspected of carrying illicit cargo, one of the parties can ask for permission to board and search such a vessel. ${ }^{19}$

As was mentioned above, the PSI was able to secure significant, although implicit, support from international institutions. The most noteworthy comes from the UN. Invocations of the Proliferation Security Initiative, which is seen as a useful tool for reinforcing standard instruments in the fight against newly emerging "nexus threats" to non-proliferation, are present in the Secretary-General's report "In Larger Freedom" and in the work of the UN High-Level Panel on Threats,

17 This issue is discussed at greater length below.

18 As of January 2006, the U.S. had signed ship-boarding agreements with the following states: Belize, Croatia, Cyprus, Liberia, Marshall Islands, and Panama. For a list of shipboarding agreements, see the U.S. Department of State website, at www.state.gov/t/ isn/c12386.htm.

19

These agreements are a profound step in fostering the operational capabilities of the PSI, especially when relations between PSI interdiction activities and their conformity with the UN Convention on the Law of the Sea are creating doubts. Concerns about the PSI's consistency with the International Law of the Sea are discussed below. 
Challenges and Change. ${ }^{20}$ Implicit support for the PSI could be found also in UN Security Council Resolution 1540, which recognizes the threat to international peace and security posed by the proliferation of WMD by non-state actors and encourages countries to introduce specific measures to minimize them. ${ }^{21}$

\section{PSI Concepts}

If the PSI is not an international organization, then what is it? U.S. officials say it is an activity that puts emphasis on developing certain principles and procedures in order to facilitate the fight against the illicit trafficking of WMD-related materials. $^{22}$ The PSI has neither a statute, a secretariat, a headquarters, a budget, nor any governing bodies. It is in theory also not an exclusive club with a limited membership. All countries that indicate official support for the Initiative's aims are welcomed to join the coalition. Lack of permanent authority and structures guarantees the flexibility of this instrument and enables it to quickly adapt to the constantly changing international environment. That explains some of the Initiative's success in attracting new countries to submit their support for the PSI.

20 "While the NPT remains the foundation of the non-proliferation regime, we should welcome recent efforts to supplement it. These include UN Security Council Resolution 1540 designed to prevent non-state actors from gaining access to nuclear, chemical, and biological weapons, technology and materials, and their means of delivery; and the voluntary Proliferation Security Initiative, under which more and more States are cooperating to prevent illicit trafficking in nuclear, biological and chemical weapons." UN Secretary-General Kofi Annan, "In Larger Freedom: Towards Development, Security and Human Rights for All," (2005), available at: http://daccessdds.un.org/doc/ UNDOC/GEN/N05/270/78/PDF/N0527078.pdf; "Experience of the activities of the A.Q. Khan Network has demonstrated the need for and the value of measures taken to interdict the illicit and clandestine trade in components for nuclear programmes. This problem is currently being addressed on a voluntary basis by the Proliferation Security Initiative. We believe that all States should join this voluntary initiative." The UN HighLevel Panel on Threats, Challenges and Change (2005), available at: www.un.org/ secureworld/report.pdf.

21 These include establishing effective export controls, introducing efficient laws to punish proliferation, undertaking "cooperative action to prevent non-state actors from acquiring WMD and to end illicit trafficking in such weapons, their means of delivery and related materials" (UNSC Resolution 1540). On 14 October 2006, the UN Security Council passed Resolution 1718 in response to North Korean nuclear tests, a resolution that implicitly draws on the existing work of the PSI. It obliges member states to prevent illicit trafficking in WMD to and from North Korea, allowing them to inspect cargo shipments going to or coming from the DPRK. See U.S. Department of State, "PSI Frequently Asked Questions" (26 May 2005), available at www.state.gov/t/isn/rls/fs/46839.htm.

22 John R. Bolton, “An All-out War on Proliferation,” The Financial Times (7 September 2004), at www.state.gov/t/us/rm/36035.htm. 
The PSI differs from existing frameworks of the non-proliferation regime by recognizing that today's threats of weapon proliferation derive from a different security environment than in the past. "By targeting key supplier states like North Korea, and now non-state black market networks similar to A. Q. Kahn's, PSI participants are attempting to tackle proliferation at its source." 23 But there should be no mistake: the PSI does not aspire to be a separate regime inconsistent with current non-proliferation mechanisms. It was designed to reinforce them. ${ }^{24}$

Although the PSI does not have permanent structures, it coordinates its activities through meetings of operational experts (seventeen meetings of the so-called Operational Experts Groups had taken place by January 2007). ${ }^{25}$ These meetings gather together experts from countries that are actively engaged in PSI activities and are organized on a regular basis in order to focus on the prospects and areas of future cooperation. ${ }^{26}$ So far, there have been two more structured meetings that assembled a larger number of participants. Both of them took place in Poland. The first one, held in June 2004 in Kraków (to coincide with the first anniversary of the PSI), was attended by delegates representing more than sixty countries. The second one, held on 23 June 2006 in Warsaw and known as the High-Level Political Meeting of the Proliferation Security Initiative, gathered around seventy states. The latter meeting was devoted to reviewing the PSI's successes and failures. It also took up a discussion of the financial aspects of WMD proliferation and ways to improve national measures "to identify, track and freeze the assets and transactions of WMD proliferators and their supporters." ${ }^{27}$ These two plenary meetings

23 Richard Bond, "The Proliferation Security Initiative: Three Years On," Basic Notes, British American Security Information Council (2 August 2006), 7; available at: www.basicint.org/ nuclear/counterproliferation/psi.htm.

"While the non-proliferation regime may serve to deter most actors, it has been proven that it does not and probably will not deter some states and potential terrorist organizations from proliferating. Therefore, it is imperative that the United States adopt a policy of counter-proliferation in addition to its non-proliferation objectives. The use of the PSI in potentially compelling Gadahfi to allow weapons inspections may serve as an example of how these two strategies can complement, and possibly enhance one another." Erin Harbaugh, "The Proliferation Security Initiative - Counterproliferation at Crossroads," Strategic Insights 3:7 (July 2004): 7. Mayuka Yamazaki, "Origin, Developments and Prospects for the Proliferation Security Initiative," Institute for the Study of Diplomacy, Edmund A. Walsh School of Foreign Service, Georgetown University (2006), 9; available at: http://isd.georgetown.edu/JFD_2006_PSA_ Yamazaki.pdf. See also U.S. Department of State, "List of Proliferation Security Initiative Operational Experts Meetings" (2006), at: www.state.gov/t/isn/c12684.htm. Winner, "The Proliferation Security Initiative," 135.

27 PSI HLPM Chairman's Statement, Warsaw, 23 June, 2006, at www.psi.msz.gov.pl. See also Bond, "The Proliferation Security Initiative: Three Years On," 2-3. 
were also used to build up stronger political support for the Initiative, which could result in facilitating further outreach activities.

\section{How It Works}

Although the main aim of the PSI is to interdict illicit transfers of WMD-related materials, it is not only about these kinds of actions. ${ }^{28}$ The PSI also represents the set of activities through which participants are working together to strengthen their abilities to stop proliferation, including workshops, seminars, and exercises. According to U.S. Department of State data, as of the end of 2006, twenty-five PSI exercises had been conducted. These include maritime, ground, and air interdiction exercises, command post exercises, and gaming exercises. In October 2006, a maritime/ground interdiction exercise called "Leading Edge" took place in Bahrain (with the participation of observers from Qatar and the United Arab Emirates), very close to Iranian territorial waters. ${ }^{29}$ Government/industry workshops and seminars enable a state's authorities to meet with representatives of private companies to discuss ways of strengthening the degree of public-private partnership in countering illicit WMD trafficking. Such workshops have been held in London (September 2006), dedicated to strengthening cooperation with the maritime; in Copenhagen in August 2004 (again devoted to maritime issues); and in Los Angeles in September 2005, dealing with air cargo transport. ${ }^{30}$

Participation in PSI exercises is beneficial in both national and international dimensions. Engaged countries are able to identify the key problems and areas (for example, communication procedures or intelligence sharing) that need to be improved in order to cooperate efficiently with other PSI partners. They also provide the opportunity to check the efficiency of interagency cooperation on a national level. Exercises are usually open to the media, which helps to build public awareness of WMD non-proliferation efforts and, more importantly, sends the warning message to potential proliferators that a significant number of countries are committed to working jointly to halt illicit trafficking of WMD.

${ }^{28}$ The issue of interdiction operations is raised in the next section.

29 Hassan M. Fattah, "U.S.-Led Exercise in Persian Gulf Sets Sights on Deadliest Weapons," The New York Times (31 October 2006), available at: www.nytimes.com/2006/ 10/31/world/ middleeast/31 gulf.html.

${ }^{30}$ U.S. Department of State, "Governments Discuss Stopping Sea-Borne Weapons Trafficking" (27 September 2006); available at: http://usinfo.state.gov/xarchives/display.html?p=washfileenglish $\& \mathrm{y}=2006 \& \mathrm{~m}=$ September $\& \mathrm{x}=20060927171830$ adynned0.1001245. 


\section{Challenges to PSI AND Its Effectiveness: Operational, Legal, Outreach Strategy}

\section{Interdiction}

Interdiction operations have been seen as a main PSI activity since its creation, and interdiction itself has been regarded as an essential tool in countering the illegal spread of WMD-related materials. Many consider the number of successfully accomplished interdiction operations as a basic indicator of the PSI's operational effectiveness. $^{31}$ The main problem is that information relating to this kind of PSI actions is classified. In May 2005, on the PSI's second anniversary, U.S. Secretary of State Condoleezza Rice mentioned that, "in the last nine months alone, the United States and ten PSI partners have quietly cooperated on eleven successful efforts." 32 The most famous example is the interdiction of the ship BBC China in October 2003. This German-owned vessel carried centrifuge components bound for Libya. U.S. and British ships followed the vessel and Italian authorities interdicted it, with the approval of the German government. This case is often cited as having influenced or at least accelerated Libya's decision to give up its nuclear program. ${ }^{33}$ However, again because of the classified nature of many of the records, it is impossible to confirm this information.

The latest signals on a number of PSI operations have come from U.S. Under Secretary of State Robert Joseph, who in his speech during the Warsaw PSI HighLevel Political Meeting stated that "between April 2005 and April 2006, the United States together with PSI participants from Europe, the Middle East and

31 Although there are views within the current U.S. administration claiming that "successful interdictions are not ultimately the best measure of the success of the PSI. The best measure of success of the PSI will be the interdictions that never happen because the weapons of mass destruction or the components of weapons of mass destruction were never shipped in the first place because the PSI successfully deterred or dissuaded would-be proliferators from engaging in this kind of activity in the first place." Stephen G. Rademaker, Assistant Secretary, Bureau of Arms Control, U.S. Department of State, "PSI Early Assessment," Hearing before the Subcommittee on International Terrorism and Nonproliferation of the Committee on International Relations, U.S. House of Representatives (9 June 2005), 5.

Jacquelyn S. Porth, "Rice Says Proliferation Security Initiative Is Yielding Results," U.S. Department of State International Information Programs (30 May 2005), available at: http://usinfo.state.gov/xarchives/display.html?p=washfile-english\&y=2005\&m=May\&x= 20050531 165844SJhtrop0.9604761\&t=xarchives/xarchitem.html.

33 Wyn Q. Bowen, Libya and Nuclear Proliferation - Stepping Back from the Brink, IISS Adelphi Paper 380 (London: Routledge, 2006), 66. 
Asia carried out roughly two-dozen interdictions." These included, among others, seizing components and dual-use materials related to Iran's nuclear program. ${ }^{34}$

The fact that secrecy is the major obstacle to assessing whether or not the PSI is successful poses a challenge for participating states to make their achievements more visible, in order to help shape public opinion. If the PSI is really efficient, why build a wall of secrecy around it? Of course, operational details or information channels must remain classified, but at least a list of successful interdictions should be revealed. ${ }^{35}$ One reason for doing so has been already mentioned: building public support for counter-proliferation efforts. The second is also pragmatic - more noticeable and widely known PSI activities would send a stronger message to proliferators.

\section{Dual-use Goods}

The ambiguous character of materials that could be subject to possible interception poses a major challenge to PSI interdiction operations. The status and nature of suspected cargo is not always clear in all situations. The Statement of Interdiction Principles calls on participants to "undertake effective measures ... for interdicting the transfer or transport of WMD, their delivery systems, and related materials...." Under existing international law it is very difficult to clearly determine which goods could be included in the category of "related materials." Many products have a dual-use nature, which means they could be used either for developing WMD or for purely civilian and peaceful purposes. This raises the question about the possible threshold (type of material, quantity, etc.) beyond which a suspected shipment would trigger an interdiction operation. ${ }^{36}$ With regard to this problem, states can disagree on whether or not WMD-related materials could pose a danger in the hands of a certain country. This could seriously affect the cohesion of PSI partners or lead to a double-standard approach to non-proliferation. Another possible question would touch on the issue of the intentions of the recipient of suspected cargo within the borders of a certain country. According to the U.S. Department of State, "The United States only pursues interdiction efforts where there is a solid case for doing so." ${ }^{, 37}$ Is this an obstacle to the PSI's effective operation?

${ }^{34}$ Robert G. Joseph, U.S. Under Secretary for Arms Control and International Security, "Broadening and Deepening Our Proliferation Security Initiative Cooperation,” Warsaw, Poland, 23 June 2006; available at: www.state.gov/t/us/ $/ \mathrm{mm} / 68269 / \mathrm{htm}$.

35 "... it is inevitable that much work is done quietly and with cooperation in sensitive channels outside public spotlight. Discreet actions often help us stay one step ahead of the proliferators and give them less insight into steps that can take to evade detection." Robert G. Joseph, "Broadening and Deepening Our Proliferation Security Initiative Cooperation."

36 Winner, "The Proliferation Security Initiative," 138.

37 U.S. Department of State, "Proliferation Security Initiative Frequently Asked Questions." 
International proliferation networks employ complicated supply routes using thirdparty states to legitimize shipments of cargo, which usually has a dual-use nature. In such a situation, PSI states possess ambiguous information on suspected cargo. If the rule is that a shipment can be interdicted only when there is absolutely no doubt about the shipment's purpose, some trafficking attempts will never be stopped.

The nature of dual-use goods poses a real challenge to the PSI, as well as to the non-proliferation regime as a whole. One solution is to further strengthen national and international legislation on export controls of such materials. The second solution requires broader intelligence sharing.

\section{Intelligence Sharing}

The challenges posed by the dual-use character of some WMD-related materials underscore the importance of the exchange of information. This is one of the key aspects of successful interdiction operations. Quick, reliable, and comprehensive information exchange allows PSI partners to undertake necessary steps in order to stop illicit shipments. ${ }^{38}$ There is little information on how, or if, intelligence sharing is going to be implemented among PSI partners. According to the U.S. Department of State, "each state that seeks to participate in the PSI is asked to identify an appropriate point of contact for sharing information.... However, sensitive information on specific interdiction cases will be shared only with those states involved in the actual interdiction effort. There is no intent to make such information available to other PSI states. ${ }^{, 39}$ In the same document we find that the U.S. does not envision multilateral intelligence sharing to facilitate PSI efforts. Clearly, the U.S. is keen to make specific information available only to certain states. This raises some questions about the PSI's coherence, especially with regard to the long list of the Initiative's supporters. Will some participant states be able to share intelligence with those that do not have appropriate clearances-for example, Yemen or Uzbekistan, both of which are on the list of PSI supporters? Certainly effective intelligence sharing mechanisms pose a major challenge for the PSI, especially given that they are essential to carrying out efficient interdiction operations.

\section{Legal Challenges}

Quite apart from the practical and operational aspects of the PSI, another major set of challenges to the Initiative's effectiveness is created by its compliance with international law, and especially with the United Nations Convention on the Law of

38 Article 2 of the Statement of Interdiction Principles stipulates that countries should develop concrete procedures to enable rapid exchange of information on proliferation activities and be able to protect this kind of classified information. 
the Sea (UNCLOS). The main accusations include fears that PSI interdiction operations could affect a state's right of "innocent passage" through the territorial waters of another country (which is guaranteed by Article 19 of the UNCLOS) and the "freedom of navigation" beyond territorial waters (guaranteed in Articles 58 and 87). Article 19 of the UNLCOS stipulates that passage is innocent when it is "not prejudicial to the peace, good order, or security of the coastal state" and further enumerates the list of cases that could justify withdrawal of the right of innocent passage for certain ships. The list is long and comprehensive, and it would not be difficult to find justification for a state to board a ship suspected of carrying WMD-related materials within its territorial waters. ${ }^{40}$

The situation is more controversial with regard to the freedom of navigation. According to Article 92 of the UNCLOS, vessels on the high seas are subject to no authority except that of the state whose flag they fly. Moreover, Article 110 of the Convention prohibits a warship from boarding a foreign ship on the high seas. There are several exceptions to this rule: a ship can be boarded if it is engaged in piracy, the slave trade, or unauthorized broadcasting; if it is without nationality; or if it is of the same nationality as the warship. That implies that unless a ship carrying WMD-related cargo falls within one of these exceptions, or the state whose flag the ship flies gives its consent, it cannot be intercepted by a foreign warship. ${ }^{41}$ That significantly narrows the number of possible scenarios under which PSI countries could carry out interdiction operations on the high seas.

PSI partners undertook several efforts to overcome these difficulties. One is the ship-boarding agreements (discussed above) signed by the U.S. with flag-of-convenience states. Another effort took place in October 2005 at the International Maritime Organization (IMO) diplomatic conference, when countries agreed to amend the Convention of the Suppression of Unlawful Acts Against the Safety of Maritime Navigation (SUA). Signatory countries agreed to add a protocol that on the one hand criminalizes terrorism and WMD proliferation but on the other hand still does not provide states with a legal basis to interdict a suspected ship. ${ }^{42}$ Despite this, it is considered a step in right direction, and one that could help to legitimize future interdiction operations.

40 Mark R. Schulman, The PSI as a New Paradigm for Peace and Security (Carlisle, PA: Strategic Studies Institute of the U.S. Army War College, April 2006), 24; available at www.strategicstudiesinstitute.army.mil/pdffiles/pub652.pdf.

41 Some parties of UNCLOS claim that such consent could be given in advance, but others would like such consent to be explicit (for example in written form) and granted on a case-by-case basis.

42 Yamazaki, “Origin, Developments and Prospects for the Proliferation Security Initiative," 12. 


\section{Outreach Strategy}

Certainly one of the important factors that will influence the PSI's success in the future is the strategy of expanding its scope. In this regard it is important to distinguish between two various dimensions of possible outreach activities: vertical and horizontal outreach. The former relates to enlarging the group of cooperating countries, while the latter dimension implies expanding the PSI's area of interest to new issues concerning counter-proliferation efforts.

Expanding the Geographical Scope. Originally consisting of eleven founding states, the PSI expanded to include around eighty countries, which reaffirmed their support for the norms set forth in the Statement of Interdiction Principles. With regard to the above-mentioned numbers, the results of vertical outreach efforts should be seen as a great success for the PSI. Nevertheless, when one takes a look at the list of the Initiative's supporters, some key countries are conspicuous by their absence. First of all, the People's Republic of China is not a member. Chinese officials explain that they have serious concerns about the PSI's legality and compliance with international law. ${ }^{43}$ China's position on the PSI was laid out in a 2004 statement, which declared that Beijing shares "the concern of PSI participants over the proliferation of Weapons of Mass Destruction and their means of delivery and favors PSI's purpose of nonproliferation," but on the other hand China "feels concerned about the legitimacy of the interdiction measures taken by PSI participants beyond the international law and their possible consequences. China always believes that, now that the purpose of nonproliferation is to enhance international and regional peace, security and stability, any nonproliferation measures should not contradict such purpose." ${ }^{, 4}$ Another justification that explains China's current position is that joining PSI could decrease its influence on the Six Party talks with North Korea. ${ }^{45}$ This would probably result in a growing sense of isolation in North Korea, and thus lead to upsetting the balance between the Six Party Talks partners, where China, together with Russia, try to present a common position in order to balance the weight of the U.S., Japan, and South Korea. ${ }^{46}$ An additional factor driving China away from support for the PSI is that it is a U.S.-

${ }^{43}$ So far, China has joined the Container Security Initiative, allowing pre-screening of containers destined for the U.S. from the ports of Shenzhen and Shanghai. See British American Security Council, "PSI: Combating Illicit WMD Trafficking, 2006"; Mark J. Valencia, The Proliferation Security Initiative: Making Waves in Asia, IISS Adelphi Paper 376 (London: Routledge, March 2006), 64.

${ }^{44}$ Ministry of Foreign Affairs of the People's Republic of China, "The Proliferation Security Initiative,” 29 June 2004; available at: www.fmprc.gov.cn/eng/wjb/zzjg/jks/kjlc/ fkswt/fksaq/ t141208.htm. 
led initiative: it was conceptualized by the government of the United States, and was introduced to the world by President George W. Bush. ${ }^{47}$ Although U.S. officials underline the PSI's flexibility and the fact that the Chinese are free to "make their own decisions about what kind of relationship they want" to have with the PSI, this message clearly does not convince Beijing. ${ }^{48}$

Some of the reasons mentioned above substantiate South Korea's stand towards the PSI. Park In-kook, the South Korean deputy foreign minister, described his country's attitude as follows: "The government has declared that it has a special status of officially supporting the goals and principles of the PSI, while not formally joining it in consideration of special circumstances on the Korean Peninsula." 49 South Korea feels that joining the Initiative and undertaking efforts to inspect ships from North Korea could potentially lead to military confrontation and, at the very least, would not facilitate further progress during the Six Party Talks.

India is another country in Asia whose participation in the PSI would be strongly desirable. Its location and its growing strategic and economic importance make this country a potentially significant ally in the fight against WMD proliferation. But there is also a flip side of the coin. India is not a part of the Non-Proliferation Treaty, and the PSI is meant to strengthen the existing non-proliferation regime. ${ }^{50}$ Mark Valencia also stresses that India's participation could worsen its relations with China, Indonesia, and Malaysia-countries that have opposing views on the PSI. The U.S. is constantly pushing India to join the Initiative, and it seems that the agreement on civilian nuclear cooperation (a part of broader strate-

47 Commander B. W. Coceano, "Proliferation Security Initiative: Challenges and Perceptions," Atlantic Council of the United States Occasional Paper (May 2004), 4; available at: www.acus.org/docs/0405-Proliferation_Security_Initiative_Challenges_Perceptions.pdf. Jacquelyn S. Porth, "International Counterproliferation Cooperation Remains Vital," U.S. Department of State International Information Programs (27 October 2006); available at: $\mathrm{http} / /$ usinfo.state.gov/xarchives/display.html?p=washfile-english\&y=2006\&m=October\& $\mathrm{x}=$ 20061027111802 sjhtrop0.6953852.

49 Norimitsu Onishi, "South Korea Won't Intercept Cargo Ships From the North," The New York Times (14 November 2006); available at www.nytimes.com/2006/11/14/ world/asia/14korea.html?fta=y. 
gic partnership between two countries) could be an attempt to bring New Delhi closer to joining the PSI, even through a back door. ${ }^{51}$

Finally, the fourth crucial actor that remains outside the PSI is Indonesia. Perhaps this is the country that is most likely to join in the near future. There are reports that the Indonesian government is preparing to endorse the Statement of Interdiction Principles and adhere to the PSI, but that it wants to be involved only in some of its aspects. ${ }^{52}$ Nevertheless, this would be a great leap ahead for the PSI, broadening its presence in Southeast Asia and enabling it to monitor one of the world's critical "chokepoints" - the Straits of Malacca, through which a quarter of global trade passes each year.

Although major players in the Asian region express concerns about the PSI's legality, they assure that they fully support its aims. Bearing in mind the strategic importance of Asia and the doubts of some key actors, it seems that this deadlock could be broken only if India or China decide to join. It looks that this could encourage and provide a pathway for other smaller states in Asia to adhere to the PSI.

An additional challenge is posed to the PSI in Central and Latin America. Only two countries, Panama and Argentina, currently participate in the Initiative. Although this region is not so crucial for possible illegal WMD transfers, it would give the PSI some additional credibility if it were able to attract such large regional actors as Brazil or Chile. Likewise in the Middle East, some countries that could be crucial for PSI efforts in the Persian Gulf remain outside the Initiative. It could prove to be beneficial if Saudi Arabia, a regional power, joined the PSI. This underlines the importance of enhancing the PSI's legal basis in order to assuage the concerns of some significant, but still undecided, countries. As a practical example of outreach activities in the region, we should mention the Polish initiative of organizing a seminar in Abu Dhabi (United Arab Emirates) devoted to

51 "As befits a major, responsible nation, and in keeping with its commitment to play a leading role in international efforts to prevent WMD proliferation, we hope that India will also take additional nonproliferation-related actions beyond those specifically outlined in the Joint Statement. We view this as a key component of the developing U.S.India strategic partnership and look forward to working with the Indian Government, as well as the international community more broadly, to further strengthen nonproliferation efforts globally. Through our ongoing bilateral dialogue we have already discussed with India such steps as endorsing the Proliferation Security Initiative Statement of Principles..." Robert G. Joseph, U.S. Under Secretary for Arms Control and International Security, Remarks before the Senate Foreign Relations Committee, Hearing on U.S.-India Civil Nuclear Cooperation Initiative (2 November 2005); available at: www.state.gov/t/us/rm/ 55968.htm.

52 Tiarma Siboro, "RI to Join U.S.-led Security Arrangement," The Jakarta Post (9 June 2006). 
the goals and principles of the PSI. The seminar, held in May 2007, was conducted in cooperation with the Emirates Center for Strategic Studies and Research (ECSSR). ${ }^{53}$ The event was attended by member countries of the Gulf Cooperation Council (Bahrain, Kuwait, Oman, Qatar, Saudi Arabia, UAE) and Yemen. All these states (besides Saudi Arabia) are listed as supporters of the PSI.

Expanding PSI Horizontally. Horizontal outreach refers to broadening the PSI's scope of concern. Some symptoms of this kind of approach are already visible in efforts to organize PSI workshops and seminars. The need for enhancing the PSI's mandate was mentioned in a speech delivered by U.S. President George W. Bush at the National Defense University in Washington in February 2004, when he proposed that the PSI should not only focus on WMD transfers, but should put more emphasis on combating the proliferation networks run by non-state actors. ${ }^{54}$ Introducing this new agenda of activities would require new tools that would enable states to deal with criminals and their material and financial assets. Since the list of PSI supporters consists of more than eighty states, it is difficult to pursue new initiatives, especially when they could be regarded as revolutionary by some participants. In the context of the growing PSI community, these steps must be taken gradually. What has endured from Bush's proposal is the effort to combat the financial aspects of proliferation. This idea was reflected in the Chairman's Statement at the June 2006 PSI High Level Political Meeting in Warsaw. The participating countries discussed the possible efforts to disrupt the financial mechanisms that support proliferators in accordance with regulations set forth in UNSC Resolutions 1540 and 1673. The Chairman's Statement urges that "each participant should consider how their own national laws and authorities might be utilized or strengthened to identify, track, or freeze the assets and transactions of WMD proliferators and their supporters."

\section{North Korea and Iran}

None can deny that the nuclear programs adopted by North Korea and Iran represent serious challenges to the non-proliferation regime as well as to the PSI. It is open to question to what extent the PSI will prove effective in supplementing efforts to suspend these programs. Because of the classified nature of many PSI activities, and the complexity of non-proliferation and counter-proliferation instruments, we may not know whether or not the PSI will turn out to be useful. The ex-

53 "WMDs Should Not Fall in Wrong Hands," Khaleej Times Online (18 May 2007); available at: www.khaleejtimes.com/DisplayArticleNew.asp?section=theuae\&xfile= data/theuae/2007/ may/theuae_may524.xml.

54 The White House, Office of the Press Secretary, "President Announces New Measures to Counter the Threat of WMD," Washington, D.C. (11 February 11 2004); available at: www.whitehouse.gov/news/releases/2004/02/20040211-4.html. 
ample of Libya strongly supports this view. The most likely scenario would envisage the PSI not being capable of stopping North Korean and Iranian efforts to further pursue their nuclear plans, but perhaps being able to slow them down.

Considering North Korea, it is too early to judge the outcomes of the initial consensus reached during the Six Party Talks in February 2007. The agreement has been described as "imperfect," and is compared to a similar agreement signed in $1994 .{ }^{55}$ Many doubt that the DPRK will fulfill its obligations under the agreement, and do not believe that it will give up its nuclear program because, for Kim Jong Il, it is North Korea's main bargaining chip with the West and a sort of insurance for his regime's survival. ${ }^{56}$ Some experts even see the agreement as a failure because Pyongyang has not explicitly agreed to verifiably eliminate their stockpile of nuclear weapons and materials. In this regard, these experts feel that the agreement, instead of encouraging a less rigorous stance toward Kim Jong Il's regime, actually underscores the importance of maintaining a deterrence policy toward North Korea, including the use of the PSI. ${ }^{57}$ Despite this fact, it must be said that the latest developments prove that the use of diplomatic means in order to resolve the crisis in DPRK have brought satisfactory results. Pyongyang not only resumed its dialogue with International Atomic Energy Agency (IAEA) but also, on 14 of July 2007, allowed international inspectors to confirm the shut-down of the nuclear facilities in Yongbyon. This is a step in the right direction, but many issues still await resolution (such as North Korea's full renunciation of all elements of its nuclear program - not only those based on plutonium, but also experiments conducted with uranium). They will be surely on the agenda of the next round of the Six Party Talks. ${ }^{58}$ To sum up, developments on the Korean Peninsula leave little space for the PSI to function, and limit its role to a deterrent factor. After the DPRK resumed the dialogue about its nuclear program, the PSI's role could be seen mainly as a deterrent factor.

55 George Perkovich, "Imperfect Progress," The Wall Street Journal (14 February 2007); available at: www.carnegieendowment.org/publications/index.cfm?fa=view\&id=19025. J. Yardley and D. E. Sanger, "In Shift, Accord on North Korea Seems to Be Set," The New York Times (13 February 2007); available at: www.nytimes.com/2007/02/13/ world $/$ asia/13korea.html? ex $=1329022800 \&$ en $=08410501 \mathrm{~b} 113903 \mathrm{c} \& \mathrm{ei}=5088 \& \mathrm{partner}=$ rssnyt\&emc=rss.

57 Bennett Ramberg, "How to Live With Nuclear North Korea," International Herald Tribune (15 February 2007); available at www.iht.com/articles/2007/02/15/ opinion/edramberg.php.

U.S. Department of State Special Briefing, "Assistant Secretary of State for East Asian and Pacific Affairs and Head of the U.S. Delegation to the Six-Party Talks Christopher R. Hill on Six-Party Talks Held in Beijing," (23 July 2007); available at: www.state.gov/r/pa/prs/ps/2007/88897.htm. 
The situation with regard to Iran is more complicated. This is because so far Iran has not displayed any readiness to obey UNSC resolutions (it has not suspended enrichment activities). The PSI exercise held in the Persian Gulf near Bahrain, just about twenty miles outside Iranian territorial waters, sent a strong signal that PSI countries (including Bahrain, Qatar, and United Arab Emirates) will work jointly to deny Iran access to WMD-related materials. "Leading Edge" was the first PSI exercise held in the Persian Gulf, and the Iranian response was hardly passive. Soon after the exercise was completed, Teheran conducted military maneuvers, during which a Shahab-3 missile was fired. ${ }^{60}$ Also, in February 2007, Iran's elite Revolutionary Guards tested its new Russian missile defense system near the strategically important Strait of Hormuz. ${ }^{61}$ The detention of fifteen British seamen in March 2007 could be regarded as another warning signal from Iran. ${ }^{62}$ In July and August 2007, Iran undertook efforts to move the issue of its nuclear program away from the purview of the UN Security Council. It has signed an agreement with the International Atomic Energy Agency (IAEA) on the "Modalities of Resolution of the Outstanding Issues" (21 August 2007), and has allowed international inspectors onto Iranian soil. However Teheran is still developing its uranium enrichment capabilities, which is why some Western countries have called for tougher sanctions. ${ }^{63}$

\section{Policy Recommendations: Towards Greater Effectiveness}

The achievements to date of the Proliferation Security Initiative are ambiguous. Most of its activities are being kept out of public view, including interdiction operations and exchanges of information. Only certain events, like exercises or workshops, are visible. Despite the fact that the PSI was invented to carry out successful interception actions, and thus counter the proliferation of WMD-related materials - and, according to official statements, it has a more or less successful record in this regard-it turns out that the real brilliance of the PSI lies not in ac-

${ }^{59}$ Hassan M. Fattah, "U.S.-Led Exercise in Persian Gulf Sets Sights on Deadliest Weapons," The New York Times (31 October 2006); available at: www.nytimes.com/2006/ 10/31/ world/middleeast/31 gulf.html.

60 "Iran to Start Military Maneuvers Days After Western-led Drills in Gulf," USA Today (1 November 2006); available at: http://www.usatoday.com/news/world/2006-11-01-Iranmilitary_x.htm.

61 "Iran Test Fires Russian Missiles near Strait of Hormuz," International Herald Tribune (7 February 2007); available at: www.iht.com/articles/ap/2007/02/07/africa/ME-GENIran-War-Games-Russia.php.

62 "Iran Seizes 15 British Seamen," Washington Post (24 March 2007); available at: www.washingtonpost.com/wp-dyn/content/article/2007/03/23/AR2007032300574.html.

63 "France Moots EU-wide Iran Sanctions," Financial Times (17 September 2007); available at: www.ft.com/cms/s/0/8572c1c0-654c-11dc-bf89-0000779fd2ac.html. 
tual interdiction operations. Rather, its strength derives from its ability to attract, during its short four years of life, around eighty states, from all continents, who have expressed their support for the PSI's principles and accept the need for a proactive approach to non-proliferation. This sends a strong signal to potential proliferators. The deterrent force of the PSI should not be underestimated, as well as its potential to strengthen cooperation among participating states and their national authorities. In this respect, the PSI has been extremely effective. During exercises, countries practice information sharing, establishing points of contact that significantly improve communication. These are key factors to successful counterproliferation activities. However, despite all these positive aspects, the PSI is not ideal. Below are some recommendations that could increase the effectiveness of this new tool:

1.It is necessary to further broaden the geographical scope of the PSI and attract several key countries which as yet remain outside the PSI community. This would further legitimize the Initiative's activities and improve its effectiveness. Crucial countries include China, Indonesia, India, Brazil, and Saudi Arabia.

2.Expanding the PSI could be facilitated by strengthening its legal basis and making it more consistent with existing international norms. This will also ensure that the Initiative will not be viewed simply as an extension of U.S. foreign policy. Entering into bilateral ship-boarding agreements is one solution to overcome restrictions on inspecting ships on the high seas, but these agreements should be signed not only by the United States, but also by other PSI countries. It is also crucial to strengthen the PSI's legitimacy within the UN framework. UNSC Resolution 1540 was a step in the right direction, although it fails to mention the Initiative explicitly. If China would join the PSI, all UNSC P-5 members would be represented in this Initiative. This could unlock the door for elaborating more comprehensive resolutions on counter-proliferation.

3. There is a need to find the risk balance between fostering the PSI's geographical outreach and broadening its horizontal scope. These two dimensions must be pursued simultaneously, and in a balanced manner. A desire to attract the attention of new states should not influence the unanimity of PSI participants and the quality of their cooperation. It also should not slow down the process of enhancing the level of cooperation within the PSI community and expanding it toward new issues. The remedy for these problems could be more equal involvement of all (new and old) participants in PSI activities. The Initiative has more than eighty supporters, but hardly half of them participate regularly in exercises. Of course, each country is free to decide the extent to which it wants to be involved, but gently encouraging passive countries to be more active should 
do no harm, but rather should contribute to improving the PSI's effectiveness and quality in the long term.

4.PSI participants should make their successes (whenever and to the extent this is possible) more visible to the public. This would help build up support and awareness concerning counter-proliferation activities in general within the community of states and among their respective populations. Such "advertising" could give some food for thought to potential proliferators.

5.Last, but not least, the non-institutionalized character of the PSI should remain its trademark. Despite what some experts try to advise, the PSI is not at present strongly influenced by shifts in the policies of participating countries (particularly the U.S.), and its institutionalization could introduce bureaucracy and procedural obstacles. ${ }^{64}$ Flexibility enables the PSI to adapt quickly to new circumstances and to attract new participants. Preserving its nature as a loose alliance of the like-minded makes the PSI an interesting twenty-first-century tool to actively counter new proliferation challenges within the framework of the existing normative non-proliferation regime.

${ }^{64}$ Yamazaki, "Origin, Developments and Prospects for the Proliferation Security Initiative"; Jofi Joseph, "The Proliferation Security Initiative: Can Interdiction Stop Proliferation?" Arms Control Today 34:5 (June 2004), available at: www.armscontrol.org/act/2004_06/Joseph.asp; Coceano, "Proliferation Security Initiative: Challenges and Perceptions," 10. 


\section{THE QUARTERLY JOURNAL}

\section{Bibliography}

Annan, Secretary-General Kofi. In Larger Freedom: Towards Development, Security and Human Rights for All., 2005.

Assistant Secretary of State for East Asian and Pacific Affairs and Head of the U.S. Delegation to the Six-Party Talks Christopher R. Hill on Six-Party Talks Held in Beijin. U.S. Department of State Special Briefing, 2007.

Bolton, John R.. "An All-out War on Proliferation." The Financial Times (2004).

Bowen, Wyn Q.. Libya and Nuclear Proliferation - Stepping Back from the Brink. London, Routledge: IISS Adelphi Paper 380, 2006.

Coceano, B. W.. Proliferation Security Initiative: Challenges and Perceptions. Atlantic Council of the United States, 2004.

Fattah, Hassan M.. "U.S.-Led Exercise in Persian Gulf Sets Sights on Deadliest Weapons." The New York Times (2006).

Fattah, Hassan M.. "U.S.-Led Exercise in Persian Gulf Sets Sights on Deadliest Weapons." The New York Times (2006).

France Moots EU-wide Iran Sanctions. Financial Times (2007).

Governments Discuss Stopping Sea-Borne Weapons Trafficking. U.S. Department of State, 2006.

Harbaugh, Erin. "The Proliferation Security Initiative - Counterproliferation at Crossroads." Strategic Insights 32, no. 7 (2004): 7.

International Counterproliferation Cooperation Remains Vital. U.S. Department of State International Information Programs, 2006.

Iran Seizes 15 British Seamen. Washington Post (2007).

Iran to Start Military Maneuvers Days After Western-led Drills in Gulf. USA Today (2006).

Joseph, Jofi. "The Proliferation Security Initiative: Can Interdiction Stop Proliferation?"Arms Control Today 34, no. 5 (2004).

Joseph, Robert G.. Remarks before the Senate Foreign Relations Committee, Hearing on U.S.-India Civil Nuclear Cooperation Initiative . U.S. Under Secretary for Arms Control and International Security, , 2005.

NATO Istanbul Summit Communiqué., 2004.

Onishi, Norimitsu. "South Korea Won't Intercept Cargo Ships From the North." The New York Times (2006). 
Perkovich, George. "Imperfect Progress." The Wall Street Journal (2007).

Porth, Jacquelyn S.. Rice Says Proliferation Security Initiative Is Yielding Results. U.S. Department of State International Information Programs, 2005.

President Announces New Measures to Counter the Threat of WMD. Washington, D.C. : The White House, Office of the Press Secretary, 2004.

PSI Frequently Asked Questions. U.S. Department of State, 2005.

PSI HLPM Chairman's Statement . Warsaw, 2006.

PSI: Combating Illicit WMD Trafficking, 2006., 2006.

Rademaker, Stephen G.. Hearing before the Subcommittee on International Terrorism and Non-proliferation of the Committee on International Relations, U.S. House of Representatives ., 2005.

Ramberg, Bennett. "How to Live With Nuclear North Korea." International Herald Tribune(2007).

Sauer, Tom. "The Nuclear Non-proliferation Regime in Crisis." Peace Review: A Journal of Social Justice, no. 18 (2005): 333.

Schulman, Mark R.. The PSI as a New Paradigm for Peace and Security. Carlisle, PA: Strategic Studies Institute of the U.S. Army War College, 2006.

Siboro, Tiarma. "RI to Join U.S.-led Security Arrangement." The Jakarta Post (2006).

Sidhu, Waheguru Pal Singh, and Ramesh Thakur. "Managing the Nuclear Threat After Iraq: Is It Time to Replace the NPT Paradigm?" In Arms Control After Iraq: Normative and Operational Challenges, 1. New York: United Nations University Press, 2006.

Simpson, John. "The Nuclear Non-proliferation Regime: Back to the Future?"Disarmament Forum, no. 1 (2004).

Statement of Interdiction Principles., 2003.

The Proliferation Security Initiative. Ministry of Foreign Affairs of the People's Republic of China, 2004.

The Proliferation Security Initiative: Three Years On. British American Security Information Council, 2006.

The UN High-Level Panel on Threats, Challenges and Change., 2005.

U.S. National Strategy to Combat Weapons of Mass Destruction., 2002. 


\section{THE QUARTERLY JOURNAL}

Valencia, Mark J.. The Proliferation Security Initiative: Making Waves in Asia. London: Routledge: IISS Adelphi Paper 376, 2006.

Van Ham, Peter. WMD Proliferation and Transatlantic Relations: Is a Joint Western Strategy Possible?. Netherlands Institute of International Relations (Clingendael Institute), 2004.

Weiner, Rebecca. Proliferation Security Initiative to Stem Flow of WMD Material. Center for Non-proliferation Studies at the Monterey Institute of International Studies, 2003.

Winner, Andrew C.. "The Proliferation Security Initiative: The New Face of Interdiction."The Washington Quarterly 28, no. 2 (2005): 130.

WMDs Should Not Fall in Wrong Hands. Khaleej Times Online, 2007.

Yamazaki, Mayuka. Origin, Developments and Prospects for the Proliferation Security Initiative. Institute for the Study of Diplomacy, Edmund A. Walsh School of Foreign Service, Georgetown University, 2006.

Yardley, J., and D. E. Sanger. "In Shift, Accord on North Korea Seems to Be Set." The New York Times (2007). 